\title{
The Touchable Smoking Social Costs
}

Fé Fernández Hernández MD ${ }^{1}$, Ledya Fernández Leal PhD², Efraín Sánchez González MD ${ }^{3}$, Bergelino Zaldívar Pérez PhD ${ }^{4}$

${ }^{1}$ Auxiliary Professor. Faculty of Medical Science at University of Medical Science of Havana.

${ }^{2}$ Titular Professor. Faculty of Economy at University of Havana.

${ }^{3}$ Auxiliary Professor. Faculty of Medical Science at University of Medical Science of Havana.

${ }^{4}$ Auxiliary Professor. University of sciences from the physic culture and sport "Manuel Fajardo".

*Corresponding Author: Fé Fernández Hernández, Auxiliary Professor. Faculty of Medical Science at University of Medical Science of Havana.

Received date: March 27, 2021; Accepted date: April 07, 2021; Published date: April 12, 2021

Citation: Fé F Hernández, Ledya F Leal, Efraín S González, Bergelino Z Pérez. (2021) The Touchable Smoking Social Costs. Journal of Clinical and Laboratory Research. 2(3) DOI: 10.31579/jclr.2021/016

Copyright: @2021 Fé Fernández Hernández. This is an open-access article distributed under the terms of the Creative Commons Attribution License, which permits unrestricted use, distribution, and reproduction in any medium, provided the original author and source are credited.

Abstract
Introduction: In economic terms the costs may be classified as touchable and untouchable. The
touchable costs are given for a relative easiness to be measured and quantified too. At present health
context one of the items with more research needs respect to the economic impact is the smoking.
Objective: To describe the main touchable costs related to smoking as risk factor.
Methods: Was made a descriptive research about the main touchable costs related to smoking as risk
factor. As teoricals methods were used the inductive - deductive, analysis and synthesis and comparative.
As empiric method was used the bibliographic research,
Results: Was made a conceptual disaggregation of touchablecost because of smoking to facility it
accounting to be staring point to futures similar economic evaluations.
Conclusions: Beginning of identify the smoking particularities like multicausal risk factor was made a
general conceptual disaggregation of touchablecost because of smoking to facility since a social point of
view, the smoking economic accounting.
Key words: cost; smoking; accounting

\section{Introduction}

The illness cost researches are considered a quantitative and valuated estimationin monetary unit from the illness or risk factor researched impacting over the economic resources use $[1,2]$.

Usually is used the concept of social cost in the illness cost research. This concept is understood as the sum of all cost attributable to each person member from the researched population [3].

In economic terms the costs may be classified as touchable and untouchable. The touchable costs are given for a relative easiness to be measured and quantified too. Much time these are expressed in monetary terms. These are the costs taken as reference for this research. The untouchable can't be measured easily and then usually are expressed in social terms as reduction of life quality or reduction of life expectancy for example [4].

The direct costs include the use of health resources for the direct attention to patients $[5,6]$. The indirect costs are given by the whole values didn't obtained because of the existence of the illness or the risk factor researched $[7,8]$. Mainly these are touchable costs because of an illness or risk factor.
At present health context one of the items with more research needs respect to the economic impact is the smoking [9]. For them the objective of this research is to describe the main touchable costs related to smoking as risk factor.

\section{Materials and methods}

Was made a descriptive research about the main touchable costs related to smoking as risk factor. As teoricals methods were used the inductive deductive, analysis and synthesis and comparative. As empiric method was used the bibliographic research.

\section{Results}

The conceptual disaggregation from the touchable smoking costs will serve of start point for the integral accounting from these costs type. Since a social perspective these costs may be disaggregate as smoking direct costs and smoking indirect costs as following:

\section{Smoking direct health costs:}

These are the costs attributable to smoking assumed by health institutions in the direct attention to patients. In this point is important to appoint that the whole health spends by active smokers isn't attributable to smoking. Also a part from the no-smoker health spends is attributable to smoking 
agree to the exposition to tobacco smoke from no smoker people. That's why the economic burden attributable to smoking by morbidity is a main rate to measure this cost attributable to smoking [10,11].

Smoking direct no-health costs: these are the costs attributable to smoking assumed by no-health institutions close related with the morbidity attributable to smoking. Much of these costs are given by the Social Security. For example, the insure and waiver payments because of the morbidity and mortality attributable to smoking [12].

\section{Indirect costs by labor productivity lose attributable to smoking: absolute and relative}

Related to individual self-health smoking is a risk factor close associated to the labor performance because of the smoking impact over morbidity and mortality because of no-communicative illness attributable to smoking [13].

Authors classify the labor productivity lose attributable to smoking in absolute and relative. The absolute is related with mortality because the effect is irreversible. The smoking cost by absolute labor productivity lose is given by the existence of the earlier smoker death generally before arrive to the retire age [14].

The relative labor productivity lose because of smoking is close related to morbidity attributable to smoking. Its main characteristic is the reversibility with the possibility to reincorporate to the job market [15].

At same time the relative labor productivity lose attributable to smoking may be by worker physic absence and by worker no-physic absence. The first is given by the physic absence from the smoker worker to the workplace because of the morbidity attributable to smoking. The second is given by the exploitation from the worktime given the physic presence of the smoker worker at workplace because of the labor time used to smoke [16]. In both case, the smoking cost by labor productivity lose is given by the whole economic values didn't obtained because of the socioeconomic smoking impact.

Each smoking cost has a self estimation way. The previous identification from the main smoking social cost may be an important reference for other researches about the smoking social cost and the smoking socioeconomic too.

\section{Conclusions}

Since the identification of the smoking particularities was made disaggregation about the main touchable costs related to smoking. This disaggregation may easier the quantification of the social smoking impact.

\section{References}

1) García Fariñas A, Marrero Araujo M, Jiménez López G, Gálvez González AM, Hernández Crespo L, Reyes Jiménez A. (2016)
Definiciones y clasificaciones básicas para el estudio de los costos en salud. Revista INFODIR [revista en Internet].

2) Linares Pérez Nivaldo. (2015) Aplicación de los enfoques de salud de la población y los determinantes sociales en Cuba. Rev Cubana Salud Pública [Internet].

3) Fernández Hernández F, Sánchez González E (2019). Diploma Course: "The Social Smoking Cost in the National Economy", A Necessary and Appliable Tool. HSOA Journal of Community Medicine and Public Health Care. 6:052.

4) Fernández García A, Triana Casado I, Villar Valdés R. (2012) Direct costs of open angle primary glaucoma. Rev Cubana Salud Pública [Internet]. 38(4): 336-354.

5) García Fariñas A. (2016) La Economía de la Salud: una mirada desde la ética. Infodir (Revista de Información para la Dirección en Salud). 12(22):31-46.

6) Fernández F, Sánchez E. (2017) Carga epidemiológica vs carga económica del tabaquismo por morbilidad. Rev. Ciencias Médicas de Pinar del Río. Marzo -abril. vol. 21(2) 210-216.

7) Sánchez E, Fernández F. (2018) Costo social por pérdida absoluta de productividad laboral. Revista Cubana de Salud y Trabajo. 19(1):33-39.

8) Fernández F, Sánchez E. (2017) Pérdida de productividad laboral por el consumo de cigarrillos en la jornada laboral. Revista Cubana de Salud y Trabajo. 18(3):9-12.

9) Cardentey García Juan. (2016 ) El tabaquismo: un flagelo nocivo para la humanidad. AMC [Internet]. 20(2):114-117.

10) OMS. Convenio Marco de la OMS para el control del Tabaco (CMCT OMS). (Internet) Disponible en

11) Marimón Torres Eugenia Rita, Orraca Castillo Odalys, Casanova Moreno María Caridad, Paredes Díaz Roberto, Mendoza Ferreiro Maricel. (2013 ) Prevalencia de factores de riesgo de enfermedades no transmisibles. Rev Ciencias Médicas [Internet]. 17(2): 2-12.

12) Kuipers MAG, Partos T, McNeill A, et_al. (2019) Smokers' strategies across social grades to minimise the cost of smoking in a period with annual tax increases: evidence from a national survey in England. BMJ Open ;9: e026320.

13) Arredondo A, Recaman AL, Pinzon C, Azar A. (2018) Financial consequences from smoking-related diseases in middle-income countries: Evidence and lessons from Mexico. Int J Health Plann Mgmt. 33:e454-e463.

14) Sánchez E, Fernández F. (2016) La pérdida de productividad laboral atribuible al tabaquismo. Revista Cubana de Salud y Trabajo. 17(2):57-60.

15) Fernández Hernández F. Sánchez González E. (2020) Smoking incidence over the labor health. Journal of Medical Care Research and Review. 3(8): 417-419.

16) Fernández Hernández F., Sánchez González E. (2020) The social and economic inequity from smoking in Cuba. Annals of Medical \& Surgical Case Reports. 2(2). 